\title{
MENJADI GURU PROFESIONAL DALAM MENGHADAPI DINAMIKA PERSAINGAN GLOBAL
}

\author{
Abdul Hobir \\ Universitas Islam Madura \\ Email: hobir6288@gmail.com \\ Sugeng Kurniawan \\ Institut Agama Islam Yasni Bungo \\ Email: sugengkurniawan@staiyasnibungo.ac.id
}

\begin{abstract}
As a consequence of the enactment of the ASEAN Economic Community, there will be a free flow of labor, goods, services, capital and investment markets among countries in the ASEAN region. This condition will be an opportunity and also a challenge that must be faced by all Indonesian people, especially teachers who have a central role in building the nation. Anticipating changes that are so fast and the challenges that are getting bigger and more complex, there is no other way for the teacher except just trying everything to improve the competitiveness of the teachers and other academic products and services. Imagine an ideal figure who has great competence, sincerely educates with a high work ethic, full of authority, becomes an example with all the words uttered and his behavior imitated, of course our thoughts are immediately fixed on the figure of a teacher. He was the teacher who was ordained as a professional. It's just that the figure more often meets the imagination, because in reality, the more days it feels more difficult to find such a great figure. In fact, the figure is so missed by all students who are very thirsty for knowledge and thirst for exemplary. Character education that is always echoed, coupled with a new curriculum that emphasizes attitudes and skills, of course will only be a waste if the teacher who is at the forefront of behavior changes in his students has not been able to demonstrate adequate character, attitudes, and skills, which is often summarized in a "professional" word.
\end{abstract}

Keywords: Education, Professional Teachers, Global Competition.

\begin{abstract}
Abstrak
Sebagai konsekuensi pemberlakuan Masyarakat Ekonomi ASEAN (MEA) maka akan terjadi arus bebas pasar tenaga kerja, barang, jasa, modal, dan investasi diantara negara-negara di kawasan ASEAN. Kondisi ini akan menjadi peluang dan sekaligus tantangan yang harus dihadapi oleh segenap bangsa Indonesia, khususnya para guru yang mempunyai peran sentral dalam membangun bangsa. Mengantisipasi perubahan-perubahan yang begitu cepat serta tantangan yang semakin besar dan kompleks, tiada jalan lain bagi guru kecuali hanya mengupayakan segala cara untuk meningkatkan daya saing para guru serta produk- produk akademik dan layanan
\end{abstract}

Nur El-Islam, Volume 6, Nomor 1, April 2019 
lainnya. Membayangkan sosok ideal yang punya kompetensi besar, ikhlas mendidik dengan etos kerja tinggi, penuh kewibawaan, menjadi teladan dengan segala tutur kata yang diguguserta perilakunya ditiru, tentu pikiran kita langsung tertuju pada sosok seorang guru. Dialah guru yang ditahbiskan sebagai seorang profesional. Hanya saja sosok tersebut lebih kerap memenuhi imajinasi, karena dalam realita, semakin hari terasa semakin sulit menemukan sosok sedemikian hebat itu. Padahal, sosok tersebut begitu dirindukan semua peserta didik yang sangat dahaga akan ilmu dan haus akan keteladanan. Pendidikan berkarakter yang selalu digaungkan, ditambah lagi dengan kurikulum baru yang mengedepankan sikap dan keterampilan, tentu cuma akan menjadi sebuah kesia-siaan andaikata guru yang berada di garda terdepan perubahan perilaku peserta didiknya tersebut belum mampu menunjukkan karakter, sikap, serta keterampilan yang memadai dan menginspirasi, yang sering dirangkum dalam sebuah kata "profesional" itu.

Kata kunci: Pendidikan, Guru Professional, Persaingan Global.

\section{A. Pendahuluan}

Pada penghujung tahun 2015 para pemimpin negara-negara ASEAN menghadiri Konferensi Tingkat Tinggi (KTT) ke-26 ASEAN. KTT ke-26 ASEAN yang diselenggarakan di Malasyia ini telah menyepakati deklarasi penguatan kerjasama ASEAN dan upaya penguatan serta memberlakukan suatu komunitas baru yang disebut dengan Masyarakat Ekonomi Asean (MEA). ${ }^{1}$ Pemberlakuan Masyarakat Ekonomi ASEAN akan membentuk suatu tatanan baru bagi bangsabangsa di kawasan ASEAN. Sebagai konsekuensi pemberlakuan MEA maka akan terjadi arus bebas pasar tenaga kerja, barang, jasa, modal, dan investasi diantara negara-negara di kawasan ASEAN. Kondisi ini akan menjadi peluang dan sekaligus tantangan yang harus dihadapi oleh segenap bangsa Indonesia, khususnya para guru yang mempunyai peran sentral dalam membangun bangsa.

Mengantisipasi perubahan-perubahan yang begitu cepat serta tantangan yang semakin besar dan kompleks, tiada jalan lain bagi guru kecuali hanya mengupayakan segala cara untuk meningkatkan daya saing para guru serta produk-produk akademik dan layanan lainnya, yang antara lain dicapai melalui peningkatan mutu pendidikan. Hanya melalui pendidikan yang benar bangsa ini dapat

\footnotetext{
${ }^{1}$ http://www.wapresri.go.id/menghadiri-penutupan-ktt-ke-26-asean/
} 
membebaskan diri dari belenggu krisis multidimensi yang berkepanjangan. Melalu pendidikan bangsa ini bisa membebaskan masyarakat dari kemiskinan, dan kerterpurukan. Melalui pendidikan pula, bangsa ini mengembangkan sumber daya manusia yang memiliki rasa percaya diri untuk bersanding dan bersaing dengan bangsabangsa lain di dunia, bahkan dalam dalam era kesemrawutan global. Tanpa pendidikan yang kuat, dapat dipastikan bangsa Indonesia akan terus tenggelan dalam keterpurukan.

Salah satu kunci penting dalam membangun kualitas pendidikan adalah guru. Supardi mengatakan bahwa guru sangat menentukan keberhasilan pendidikan suatu negara. ${ }^{2}$ Bahkan guru pada hakikatnya merupakan komponen strategis yang memilih peran yang penting dalam menentukan gerak maju kehidupan bangsa. Selain itu, keberadaan guru merupakan faktor condisio sine quanon yang tidak mungkin digantikan oleh komponen manapun dalam kehidupan bangsa sejak dulu, terlebih-lebih dalam era kontemporer ini. ${ }^{3}$

Oleh karena itu keberadaan guru yang profesional merupakan syarat mutlak hadirnya sistem dan praktik pendidikan yang bermutu. Merekalah yang akan menghantarkan anak-anak Indonesia menjadi masyarakat cerdas, kreatif, inovatif, memiliki skil, ketrampilan atau keahlian, dan juga memiliki integritas kuat untuk membawa bangsa ini menjadi bangsa besar yang dihargai oleh bangsa-bangsa lain di dunia. Kurikulum yang baik, tidak akan bermakna apa-apa untuk prestasi akademik siswa dan mahasiswa, jika guru atau dosennya tidak profesional. Gedung sekolah yang baik tidak akan bisa menghantarkan para siswanya menjadi anak-anak cerdas berdaya saing, jika gurunya tidak profesional. Kampus yang megah tidak akan mampu melahirkan sarjana cerdas, berdaya saing jika guru tidak profesional.

Sudah sangat akrab terdengar oleh telinga, sebuah pameo: "Guru kencing berdiri, murid kencing berlari”. Bagaimana jika guru kencing berlari? Bisa jadi murid akan kencing sambil berlompat tinggi.

\footnotetext{
${ }^{2}$ Supardi, Kinerja Guru (Jakarta: Raja Grafindo, 2013), h. 1.

${ }^{3}$ Uzer Usman, Menjadi Guru Profesional (Bandung: Remaja Rosda Karya, 2011), h. 7.
} 
Mungkin banyak orang yang mendengar pameo ini hanya sebagai suatu lawakan yang memancing tawa, padahal jika ditelaah dan direnungkan lebih dalam lagi, pameo tersebut bukan sekadar luculucuan, melainkan sebuah sindiran keras kepada semua orang yang mengaku dirinya sebagai guru, apakah perilakunya selama ini layak ditiru atau tidak? Apakah guru benar-benar menjadi orang yang digugu dan ditiru, atau malah sudah bergeser menjadi orang yang digugu walaupun keliru? Dan akan lebih hina lagi jika akronim guru itu semakin berubah, manjadi orang yang belagu dan keliru. Guru yang digugu dan ditiru, mungkin itu gambaran paling singkat mengenai pribadi yang profesional.

Guru yang tidak hanya mengajar dan melatih, tetapi juga mampu mendidik dan menjadi uswatun hasanah bagi setiap peserta didiknya. Bukankah sudah banyak guru profesional, apalagi setelah mereka lulus sertifikasi baik itu jalur portofolio, Pendidikan dan Latihan Profesi Guru (PLPG), maupun program Pendidikan Profesi Guru (PPG)? Bisa jadi memang demikian, walaupun penulis di sini memiliki pandangan yang sedikit berbeda. Bukankah banyak juga guru yang memiliki banyak sertifikat namun sedikit kemampuan? Bukankah masih banyak yang hanya mengumpulkan tanda bukti keikutsertaan pelatihan atau seminar, padahal mereka tak pernah terlibat di dalamnya? Sosok guru profesional itu, idealnya adalah mereka yang tak hanya diberi gelar lewat sertifikat profesionalnya, tetapi memperlihatkan pula profesionalismenya tersebut dalam segala tindak-tanduknya. Guru yang tidak hanya memiliki ijazah kesarjanaan, namun juga kaya dengan segudang kompetensi layaknya seorang sarjana.

\section{B. Pembahasan}

\section{Pengertian Guru}

Guru adalah tulang punggung pendidikan, formal maupun non formal. Maju mundurnya Sekolah dan madrasah, sangat tergantung pada profesionalisme para gurunya. Sebaik-baik input calon siswa sekolah/madrasah jika didampingi para guru yang tidak profesional, tidak akan mampu menghantaran mereka menjadi siswa-siswa 
berprestasi, cerdas dan memiliki daya saing yang kuat. Oleh sebab itu, UU No. 14 tahun 2005 tentang Guru dan Dosen mendefinisikan guru sebagai pendidik profesional dengan tugas utama mendidik, mengajar, membimbing, mengarahkan, melatih, menilai, dan mengevaluasi peserta didik pada pendidikan anak usia dini jalur pendidikan formal, pendidikan dasar, dan pendidikan menengah. ${ }^{4}$ Pengertian ini membatasi guru dalam dua ranah yang sangat spesifik, yakni bahwa guru adalah guru pada pendidikan formal. Dengan demikian, para pendidik di pendidikan non formal tidak disebut guru. Mereka memiliki sebutan lain yang spesifik, seperti tutor, trainer, atau sebutansebutan lain yang lazim di pesantren, pendidikan diniyah dan juga di majelis ta'lim. Kemudian, guru juga hanya digunakan untuk para pendidik pada pendidikan anak usia dini, pendidikan dasar dan menengah, sementara untuk pendidikan tinggi memiliki sebutan lain yaitu dosen untuk pendidikan tinggi formal, atau sebutan lain untuk pendidikan tinggi non formal.

Guru memiliki tugas yang amat besar, yakni mendidik, mengajar, membimbing, mengarahkan, melatih, menilai dan mengevaluasi peserta didik. Tugas pertama yang sangat ditekankan dalam undangundang adalah mendidik yang dibedakan dari tugas guru mengajar. Mendidik dan mengajar memiliki konsep yang berbeda, kendati tidak bisa distratifikasi bahwa mendidik lebih penting dari pada mengajar atau sebaliknya. Dengan berkembangnya konsep constructivism dalam pembelajaran, memang berubah pula konsep mengajar, karena guru tidak boleh menguasai kelas untuk mentransformasikan ilmu dan pengetahuannya pada para siswa, karena kalau guru mulai berceramah, harus diyakini bahwa banyak siswa yang masih sedang memikirkan fokus lain di luar pelajaran yang dia sampaikan. Dan apakah siswa sedang membutuhkan apa yang diajarkan guru, dan masih banyak pertanyaan yang pada ujungnya, biarkan siswa mempelajari bahan- bahan ajar yang disediakan, dan guru hanya mengarahkan fokus pelajaran mereka, dan mendampingi para siswanya belajar, lalu mengarahkan agar siswa menyimpulkan sendiri

\footnotetext{
${ }^{4}$ Undnag-Undang No. 14 tahun 2005 tentang Guru dan Dosen, Pasal 1 ayat 1
} 
pengetahuan yang mereka pelajari pada hari itu, atau mereka latih bersama teman-teman kelas mereka yang didampingi oleh guru.

Dengan demikian, mengajar kini berubah konsep menjadi empat variabel utama, yakni bahwa mengajar adalah pekerjaan intelektual, mengajar adalah pekerjaan yang sangat variatif, mengajar adalah sharing, dan mengajar adalah pengembangan bahan yang terus menantang. ${ }^{5}$ Mengajar adalah pekerjaan intelektual, yakni bahwa guru harus terus mengembangkan pengetahuannya dalam bidang ilmu yang menjadi tanggung jawabnya, baik melalui penelitian, penulisan paper, diskusi, seminar dan yang sebangsanya, sehingga tidak tertinggal dari pengetahuan yang bisa diakses oleh para siswanya.

Mengajar adalah pekerjaan variatif, bukan semata mendampingi, mengawasi para siswanya belajar, tapi juga memvisualisasi teori-teori yang dipelajari, baik di laboratorium maupun di tempat lainnya, bahkan guru disarankan untuk melakukan membawa siswa ke dalam konteks yang sebenarnya dari pelajaran yang mereka pelajari lewat teknik Contextual Teaching and Learning (CTL), dan bahwa mengajar adalah sharing, yakni siswa harus sharing satu sama lain, dan dalam beberapa keadaan justru guru yang harus sharing pada siswanya, jangan biarkan pula siswa menyimpulkan sendiri tanpa validasi dari guru. Dan terakhir guru harus terus mengembangkan bahan ajar bagi para siswanya agar mereka tidak tertinggal oleh perkembangan sains di dunia, setidaknya bisa mengikuti perkembangan-perkembangan yang ada pada berbagai asesmen atau bahkan perkembangan yang dibutuhkan dunia kerja.

Itulah mengajar dalam pengertian sekarang yang sedang lebih benyak berkiblat pada teori constructivism, walaupun dalam beberapa konteks praktik di sekolah/madrasah masih banyak memerlukan model mengajar berbasis teori behaviourism. Sementara itu, tugas guru sebagai pendidik lebih terfokus pada perubahan dan pembentukan karakter baru sesuai dengan yang diidealkan oleh masyarakatnya. Di

${ }^{5}$ Suzanne M Wilson, Penelope L Peterson, Theories of Learning and Teaching What Do They Mean for Educators, Working Paper, National Education Association, Washington DC 2006, p. 9. 
Indonesia, gagasan besar yang diinginkan masyarakat itu tertuang pada UU No.20 tahun 2003, yang menegaskan bahwa Pendidikan adalah usaha sadar dan terencana untuk mewujudkan suasana belajardan proses pembelajaran agar peserta didik secara aktif mengembangkan potensi dirinya untuk memiliki kekuatan spiritual keagamaan, pengendalian diri, kepribadian, kecerdasan, akhlak mulia, serta keterampilan yang diperlukan dirinya, masyarakat, bangsa dan Negara. ${ }^{6}$ Sejalan dengan pengertian tersebut, pendidikan di Indonesia diarahkan pada tujuan yang sangat ideal, yakni berkembangnya potensi peserta didik agar menjadi Marusia yang beriman dan bertakwa kepada Tuhan Yang Maha Esa, berakhlak mulia, sehat, berilmu, cakap, kreatif, mandiri, danmenjadi warga negara yang demokratis serta bertanggung jawab. ${ }^{7}$

Memang agak sulit membedakan antara pendidikan dan pengajaran. Oleh sebab itu, ada juga yang mengartikan pendidikan sebagai proses mendidik atau proses mengajar. ${ }^{8}$ Akan tetapi, fokus pengembangan pembelajaraan adalah dinamisasi teknik dan metode untuk mendorong para siswa berpartisipasi dalam belajar dan mampu memformulasikan kesimpulan dari proses pembelajaran yang mereka lalui.

Kemudian, pembelajaran juga lebih banyak berfokus pada kajian alat, sarana atau media yang perlu dipersiapkan untuk memperkuat pemahaman siswa terhadap bahan-bahan yang mereka pelajari, suasana belajar yang bisa dikembangkan, serta kesiapan kejiwaan para siswa yang akan belajar. Pembelajaran lebih fokus berbicara proses di dalam kelas, di laboratorium atau proses interaksi siswa dengan sumber belajar di luar kelas atas arahan dan bimbingan guru. Pembelajaran banyak digunakan untuk menjelaskan proses pendidikan yang bisa dikontrol oleh guru. Sementara pendidikan lebih banyak memperhatikan proses pembentukan kepribadian yang holistik, baik

\section{1 ayat 1 .}

${ }^{6}$ Undang-Undang No. 20 tahun 2003 tentang Sistem pendidikan Nasional, Pasal

${ }^{7}$ Ibid., pasal 3.

${ }^{8}$ Judith Lloyd Yero, The Meaning of Education, dalam Teachers Mind Resources: http:// www. Teachers Mind. com, 2002. 
aspek kekuatan intelektualitas, skil ketrampilan dan keahlian, emosionalitas, spiritualitas dan juga kesehatan fisik. Oleh sebab itu, fokus pendidikan lebih banyak pada kajian cetak biru, pelibatan banyak unsur untuk menjaga proses pembentukan para siswa untuk menjadi warga negara yang cerdas berdaya saing, baik dalam aspekaspek yang bisa dikontrol guru maupun aspek-aspek kehidupan sosial yang tidak dikontrol oleh guru, dengan tetap mengontrol tindakantindakan siswa di dalamnya lewat pelaporan yang dievaluasi oleh guru.

Sejalan dengan itu, guru juga harus memberikan bimbingan dan arahan pada para siswanya agar perubahan-perubahan yang distimulasi oleh penambahan pengetahuan di sekolah, tidak terganggu oleh tradisi-tradisi yang sudah berkembang dalam kehidupan sosial atau keluarga yang mungkin kurang atau tidak produktif mendukung perubahan tersebut. Untuk adaptasi siswa dalam kehidupan keluarga dan kehidupan sosial, guru tidak bisa mengawasi langsung para siswanya, tapi mereka tidak bisa lepas tangan terhadap kehidupan siswanya di dua lembaga yang sangat berpengaruh terhadap pendidikan para siswa, keluarga dan masyarakat. Tugas tersebut merupakan implikasi dari tugas guru sebagai pendidik yang memiliki tugas membimbing serta mengarahkan para siswanya untuk menjadi seseorang sesuai dengan yang dirumuskan dalam tujuan pendidikan nasional.

Guru tidak sekedar harus memiliki ilmu pengetahuan sebagai bekal dalam mendampingi siswa belajar, memiliki kecakapan memiliki kecakapan membelajarkan para siswa, tapi juga harus memiliki integritas untuk melayani, mendampingi, membimbing dan mengarahkan para siswanya belajar, di sekolah, keluarga dan juga dalam kehidupan sosial. Oleh sebab itu, pekerjaan guru harus menjadi profesi, yang memerlukan ilmu dan kecakapan hasil pendidikan dan latihan, menjadi kebanggan bagi para guru sendiri, dan memberikan penghasilan yang layak untuk kehidupan keluarga dan sosial mereka. Sejalan dengan semangat reformasi yang memiliki agenda strategis memperbaiki sektor pendidikan, kini guru adalah profesi sebagaimana dokter, pengacara, akuntan, dan profesi-profesi lainnya. Pekerjaan 
guru hanya bisa dimasuki oleh mereka yang berpendidikan untuk pekerjaannya itu, dan guru bekerja penuh waktu sebagai andalan dalam hidupnya, dan memiliki kebanggan dengan profesinya sebagai guru.

Konsekwensi dari posisi sebagai pekerjaan profesi, untuk menjadi guru, siapapun harus memenuhi kualifikasi dan kompetensi serta memiliki sertifikat pendidik. Kualifikasi minimal seorang guru, sebagaimana ditegaskan pada pasal 8 dan 9 UU No. 14 tahun 2005, bahwa Guru wajib memiliki kualifikasi akademik, kompetensi, sertifikat pendidik, sehat jasmani dan rohani, serta memiliki kemampuan untuk mewujudkan tujuan pendidikan nasional. Kemudian Kualifikasi akademik sebagaimana dimaksud dalam Pasal 8 diperoleh melalui pendidikan tinggi program sarjana atau program diploma empat. ${ }^{9}$ Semua guru pendidikan formal dari jenjang Pendidikan Anak Usia Dini (PAUD) sampai jenjang pendidikan menengah, harus berpendidikan sarjana, atau diploma IV.

Bersamaan dengan itu, bahwa setiap guru juga harus memiliki empat kompetensi sebagaimana ditegaskan dalam UU No. 14 tahun 2005 pasal ke-10, yang berbunyi bahwa guru harus memiliki kompetensi pedagogik, kompetensi kepribadian, kompetensi sosial, dan kompetensi profesional yang diperoleh melalui pendidikan profes. ${ }^{10}$ Guru harus mampu mengajar dengan mengembangkan berbagai teknik agar para siswa aktif belajar, kemudian guru juga harus bangga dengan profesinya sebagai seorang guru, dan mampu meyakinkan orang lain untuk mendukung kemajuan sekelah. Terakhir guru harus menguasai bahan ajar dengan baik, mengikuti perkembangan ilmu pengetahuan dalam bidang yang menjadi tanggung jawabnya, dan menjadi pembelajar sepanjang hayat, long life learner.

\footnotetext{
${ }^{9}$ Undang-Undang No. 14 tahun 2005 tentang Guru dan Dosen, Bab IV pasal 8 dan 9

${ }^{10}$ Ibid., pasal 10.
} 


\section{Teori Profesionalisme Guru}

Telah banyak dokumen yang dapat dipelajari terkait profesionalisme guru serta serangkaian upaya yang dapat ditempuh untuk mengembangkannya. Undang-Undang Nomor 20 Tahun 2003 tentang Sistem Pendidikan Nasional memberi amanat kepada pemerintah untuk mengusahakan dan menyelenggarakan suatu sistem pendidikan nasional yang bertujuan meningkatkan keimanan dan ketaqwaan kepada Tuhan Yang Maha Esa serta akhlak mulia dalam rangka mencerdaskan kehidupan bangsa. Kemudian Undang-Undang Nomor 14 Tahun 2005 tentang Guru dan Dosen mengamanatkan bahwa guru sebagai tenaga profesional bertugas mewujudkan tujuan pendidikan nasional, yaitu berkembangnya potensi peserta didik agar menjadi cakap, mulia, sehat, berilmu, kreatif, mandiri, dan menjadi warga negara demokratis dan bertanggung jawab, serta sehat jasmani dan rohani.

Undang-Undang Nomor 14 Tahun 2005 Pasal 8 menyatakan guru wajib memiliki kualifikasi akademik, kompetensi, sertifikat pendidik, sehat jasmani dan rohani, serta memiliki kemampuan untuk mewujudkan tujuan pendidikan nasional.

Pasal 10 (ayat 1) menyatakan kompetensi guru sebagaimana dimaksud dalam Pasal 8 meliputi kompetensi pedagogik, kompetensi kepribadian, kompetensi sosial, dan kompetensi profesional. Dan tujuan akhir dari semua itu adalah terbitnya sertifikat pendidik sebagai bentuk legalitas bahwa seorang guru dinyatakan profesional di bidangnya, sebagaimana maksud Pasal 11 dalam UU tersebut.

Pertanyaan retoris yang seringkali menjadi muncul adalah, benarkah sertifikat pendidik itu menjamin secara penuh bahwa guru yang memperolehnya itu adalah benar- benar profesional? Dijaminkah oleh sertifikat itu, bahwa mereka yang memilikinya memiliki pula kompetensi pedagogik, kompetensi kepribadian, kompetensi sosial, dan kompetensi profesional?

Andaikata masih banyak yang meragukan hal tersebut, maka semakin terbukalah jawaban bahwa guru bersangkutan masih belum profesional. Karena hakikat profesional adalah adanya kepercayaan (to 
profess means to trust) dan keyakinan (to believe in) ${ }^{11}$. Untuk lebih menjernihkan permasalahan ini, mari lihat kembali apa saja indikator kompetensi yang harus dimiliki oleh guru profesional. Setelah itu sama-sama kita ukur, sudah sedalam apa indikator itu melekat dalam diri kita sebagai guru.

Pertama, kompetensi pedagogik. Kompetensi ini menyangkut kemampuan seorang guru dalam memahami karakteristik serta potensi yang dimiliki oleh peserta didiknya melalui berbagai cara. Cara yang utama yaitu dengan memahami peserta didik melalui perkembangan kognitifnya, merancang pembelajaran dan pelaksanaan pembelajaran serta evaluasi hasil belajar sekaligus pengembangan peserta didik. Kedua, kompetensi kepribadian. Ini merupakan kemampuan personal yang harus dimiliki oleh guru profesional dengan cara mencerminkan kepribadian yang baik pada diri sendiri, bersikap bijaksana serta arif, bersikap dewasa dan berwibawa serta mempunyai akhlak mulia untuk menjadi contoh/teladan yang baik. Ketiga, kompetensi profesional. Kompetensi profesional ini dicerminkan dengan cara menguasai materi pembelajaran secara komprehensif dan integral. Keempat, kompetensi sosial yang harus dimiliki oleh seorang pendidik melalui cara yang baik dalam berkomunikasi dengan peserta didik dan seluruh tenaga kependidikan atau juga dengan orang tua/wali peserta didik dan masyarakat sekitar. ${ }^{12}$

\section{Guru Profesional}

Profesionalisme merupakan keseluruhan antara kemampuan keilmuan teoretik, kemampuan praktis, integritas personal, akseptabilitas sosial, dan bahkan kebanggan terhadap profesi yang ditekuni. Seorang guru tidak akan bisa menjadi guru profesional bila tidak memiliki kemampuan dalam bidang atau cabang ilmu yang menjadi tanggung jawabnya, sebagaimana juga tidak bisa dikatakan guru profesional jika tidak memiliki kemampuan praktis bagaimana

${ }^{11}$ Saud, U.S.dan Sutarsih, C., Pengembangan Profesi Guru SD. (Bandung: UPI Press, 2007), h. 62.

${ }^{12}$ Ibid. 
mengajar dengan baik, yang membuat para siswa terlibat dalam proses pembelajaran, senang dalam proses pembelajaran, dan mencapai kemampuan memperoleh pengatahuan baru paling tidak 80\% dari target yang ditetapkan oleh sekolah/madrasah. Kemudian, bagaimana mungkin seorang guru itu dikatakan guru professional jika dia sendiri masih inferior dengan profesinya sebagai guru, bahkan kemudian marasa terhina dengan pekerjaannya sebagai guru. Sebaiknya dia harus bangga dengan pekerjaannya itu. Dengan bekal keyakinan akan posisinya yang sangat penting, seorang guru profesional harus mampu meyakinkan orang lain untuk turut berpartisipasi dalam membina dan mengembangkan pendidikan. Masyarakat harus turut memberi masukan-masukan pada lembaga pendidikan, turut mengawasi dan bahkan turut berpartisipasi dalam mengembangkan institusi yang menyiapkan sumber daya manusia ke depan.

Tipe ideal guru seperti itu tidak akan lahir secara genetik tanpa proses pembinaan. Stillings Candal menegaskan great teachers aren't born, great teachers are made. ${ }^{13}$ Guru yang besar tidak dilahirkan tapi diciptakan. Memang kita tidak bisa menghindari fakta sejarah ada Thales, Aristoteles, Plato, dan beberapa ilmuwan besar zaman klasik yang lahir tanpa proses pembelajaran yang didisain secara profesional. Tidak ada guru lulusan perguruan tinggi keguruan, tapi lahir ilmuwanilmuwan besar, bahkan di dunia Islam terdapat ilmuwan-ilmuwan besar seperti al Kindi, Al Farabi, Ibnu Sina, al-Razi dan bahkan Ibnu Rusyd, yang terlahir tanpa guru-guru tamatan pendidikan keguruan. Memang, fakta tersebut adalah kenyataan eksepsional yang tidak bisa dipungkiri sebagai sebuah warisan sejarah. namun untuk bisa menghantarkan anak-anak bangsa dan sebahagian besar dari mereka bisa sukses, baik dalam bidang maupun di luar bidang yang mereka tekuni, perlu pembinaan dan pengembangan kepribadian yang sistematis, terukur serta dengan menggunakan metode dan teknik

${ }^{13}$ Stillings Candal, Great Teachers are not born, they are made, case study evidence from Massachusetts Charter, Pioneer Institute Public Policy Research, White Paper Number 130, April 2015 
yang sudah teruji kehandalannya. Untuk itu, maka setiap seseorang yang mmiliki minat kuat untuk menjadi guru, dan bahkan memiliki bakat yang menonjol, tetap harus melalui proses pendidikan, karena banyak ilmu, ketrampilan dan bahkan kemampuan mengembangkan teknik pembelajaran, yang harus dipelajari mereka agar menjadi guru prfesional.

Untuk itu, sesuai statement Cara Stilling Candal, bahwa guru profesional itu dibentuk, tidak dilahirkan. Guru profesional harus dipersiapkan dengan serius melalui proses pendidikan yang sistematis, dan komprehensif, sebagaimana diatur dalam UU No. 14 tahun 2005, Bab IV pasal 8, bahwa Guru wajib memiliki kualifikasi akademik, kompetensi, sertifikat pendidik, sehat jasmani dan rohani, serta memiliki kemampuan untuk mewujudkan tujuan pendidikan nasional.

Kemudian ditegaskan pula pada pasal 9, bahwa kualifikasi akademik sebagaimana dimaksud dalam Pasal 8 diperoleh melalui pendidikan tinggi program sarjana atau program diploma empat. ${ }^{14}$ Pengaturan ini dilakukan dalam rangka memenuhi dua aspek penting penyiapan SDM bangsa ke depan, yakni:

Pertama, agar para siswa yang belajar di sekolah tidak dirugikan dengan layanan pembelajaran yang dikelola oleh guru yang tidak menguasai bahan ajar dengan baik, tidak mampu mengembangkan proses pembelajaran yang menarik tapi memintarkan, dan tidak mampu mengukur pencapaian hasil belajar siswa.

Kedua, agar proses pendidikan benar-benar berfungsi dengan baik untuk menyiapkan SDM bangsa ke depan, yang menjadi kekuatan utama pemajuan ekonomi, melalui pengembangan sektor industri, jasa atau lainnya, atau bahkan pengembangan eknomi kreatif yang dapat mendongkrak kemampuan ekonomi bangsa, karena tidak ada bangsa maju di dunia yang semata-mata mengandalkan sektor sumber daya alam tanpa didukung oleh kekuatan sumber daya manusia. Dan

\footnotetext{
${ }^{14}$ Undang-Undang No. 14 tahun 2005, tentang Guru dan Dosen, bab IV pasal 8 dan 9
} 
sumberdaya manusia yang handal adalah mereka yang terdidik baik di sekolah dan perguruan tinggi.

Kemudian untuk memperkuat profesionalisme, para calon guru yang telah menyelesaikan pendidikan jenjang sarjana harus mengikuti pendidikan profesi untuk memperoleh sertifikat pendidik. Pengaturan pendidikan profesi guru tersebut diatur dalam PP No. 74 tahun 2008 tentang guru, karena dibedakan antara pendidikan profesi guru untuk calon guru berlatar belakang pendidikan keguruan dan mereka yang berlatar belakang pendidikan non keguruan. Dan demikian pula dibedakan beban sks nya antara mereka yang akan mengajar di SMP/MTs dengan mereka yang akan mengajar di TK/RA. Bahkan Cara Stilling Candal menyarankan agar guru senantiasa diberi kesempatan untuk menambah pengetahuan, keterampilan dan pengalaman akademik, baik melalui pendidikan dan pelatihan, workshop, seminar atau bahkan mungkin mengikuti studi lanjut. Cara beragumentasi, bahwa untuk mempertahankan prestasi, sebuah sekolah harus terus meningkatkan pengetahuan, ketrampilan dan pengalaman akademik para guru muda sebagai kekuatan yang dipunyai sekolah, dengan bimbingan dan pengawasan guru senior yang telah berpengalaman dalam pelaksanaan ugas-tugas profesi mereka sebagai guru. ${ }^{15}$ Penjaminan kualitas yang harus dibangun oleh sekolah, setidaknya dengan mempersiapkan guru yang memenuhi kualifikasi, kompetensi, serta integritas mereka dalam profesi keguruannya. Dan bahkan untuk menjaga profesionalismenya, para guru harus senantiasa diberi kesempatan untuk meningkatkan kompetensi keilmuan mereka.

\section{Guru yang Bernilai}

Sepengetahuan penulis, ada lima jenis guru yang layak untuk direnungkan. Pertama, guru yang wajib keberadaannya. Saat-saat kehadirannya begitu dirindukan dan ditunggu-tunggu karena menebar banyak manfaat, sementara ketiadaannya justru akan membuat peserta didiknya sedih dan kecewa karena mereka merasa rugi tak

\footnotetext{
${ }^{15}$ Stilling Candal, Great Teachers are not born.
} 
memperoleh manfaat yang menjadi haknya. Lalu guru yang kedua, adalah guru yang sunat keberadaannya. Saat dirinya hadir akan membawa manfaat besar bagi peserta didiknya, namun saat dia tak ada, tak ada peserta didiknya yang merasa dirugikan. Jenis guru selanjutnya adalah guru yang mubah. Kehadirannya tak membawa cukup besar manfaat, begitupun ketiadaannya tak membawa kerugian yang berarti bagi peserta didiknya. Keempat, guru yang makruh keberadaannya. Ketika dia datang tak membawa manfaat, dan justru di waktu dia tak ada peserta didik malah merayakannya. Terakhir adalah guru yang haram. Datangnya menebar keburukan dengan memberi contoh tak patut, namun saat dia tak ada semua orang di sekitarnya justru merasa nyaman. Na'udzubillahi min dzalik!

Ada pantasnya kita melakukan kontemplasi, di mana keberadaan kita sesungguhnya. Apakah kita mendapat kehormatan untuk menjadi sosok guru wajib, yang selalu dinantikan kedatangannya? Bagaimanapun, guru terbaik adalah mereka yang mampu menebar sebesar-besarnya manfaat, baik itu bagi peserta didiknya, sekolah tempat bernaungnya, lingkungan kehidupannya, maupun dunia pendidikan yang menjadi ladang perjuangannya.

\section{Kemandirian Belajar Guru}

“Guru yang berhenti belajar, berhentilah mengajar!”. Mungkin ungkapan itu benar adanya, mengingat kedudukan dan peran guru yang sangat vital dalam proses pembangunan bangsa, terlebih lagi guru di jenjang pendidikan dasar dan menengah, mengingat pada jenjang inilah para peserta didik sebagai generasi penerus dan pembangun bangsa mulai dibentuk karakternya. Untuk membangun bangsa yang cerdas, mampu memecahkan masalah, serta berbudi pekerti yang baik, tentu saja memerlukan pembelajaran yang dinamis, selalu up to date, dan inovatif. Sehubungan dengan hal itu, menjadi suatu keniscayaan bahwa guru harus selalu membangun dan membekali dirinya dengan selalu belajar secara dinamis, selalu up to date, dan tak henti mencari danmenciptakan hal-hal inovatif. Dengan begitu, anak bangsa yang dididiknya pada gilirannya nanti akan menjadi anak bangsa yang cerdas, mampu memecahkan masalah, serta berbudi pekerti yang baik. 
Berkaitan dengan "guru yang tak henti belajar", tentu saja menimbulkan permasalahan baru, mengingat guru yang notabene memiliki aktivitas yang sangat padat dan kesibukan yang tiada berujung. Terkadang sulit menemukan sekedar waktu luang untuk mencoba belajar hal-hal baru bagi guru-yang tentu saja relevan dengan profesinya-karena guru harus membagi sepertiga waktunya untuk mengajar secara formal, dan sisa waktunya harus dibagi secara proporsional antara keluarga dan kebutuhan pribadi maupun sosial lainnya.

Kesulitan di atas dapat dipikirkan sebagai penghambat dalam perkembangan kemampuan profesional guru, sehingga menjadi suatu keharusan untuk dicari alternatif solusinya, apalagi jika guru-guru yang sekarang ini masih belum memiliki habits of mind yang baik, belum memiliki kemandirian dalam belajar.

Betapa pentingnya kemandirian ini dimiliki oleh siapapun, yang dalam hal ini difokuskan pada guru. Kemandirian merupakan salah satu aspek kepribadian yang sangat penting bagi individu. Seseorang dalam menjalani kehidupan ini tidak pernah lepas dari cobaan dan tantangan. Individu yang memiliki kemandirian tinggi relatif mampu menghadapi segala permasalahan karena individu yang mandiri tidak tergantung pada orang lain, selalu berusaha menghadapi dan memecahkan masalah yang ada. ${ }^{16}$

Sehubungan dengan kemandirian belajar yang sejatinya harus dimiliki guru, sebuah penelitian terhadap 126 guru dari enam kabupaten di Provinsi Jawa Barat, menunjukkan bahwa guru-guru kurang memiliki kemandirian belajar yang baik, meskipun mereka sangat menyadari betapa pentingnya untuk jadi mandiri. ${ }^{17}$ Walaupun data penelitian ini diambil dari sampel yang tidak terlalu banyak dan tak dapat digeneralisasi, namun laporan ini menjadi “tamparan keras”

${ }^{16}$ Sutisna, Pengertian Kemandirian

Belajar.[online].

Tersedia:

2010. http://sutisna.com/ artikel/ kependidikan /pengertian-kemandirian/.

${ }^{17}$ Maulana, "Kemandirian Belajar Guru Sekolah Dasar (Studi Deskriptif terhadap Guru SD dari Enam Kabupaten di Jawa Barat)”. Dalam Jurnal Mimbar Pendidikan Dasar. Volume 4, No.1, Februari 2013, h. 34-40. 
bagi wajah para guru, untuk bisa berupaya meningkatkan kemandirian belajarnya.

\section{Keteladanan Guru}

Tidak dapat dimungkiri bahwasanya guru adalah aktor utama perubahan dunia pendidikan. Tanpa guru yang profesional, maka hebatnya kurikulum, megahnya gedung sekolah, mewahnya fasilitas pembelajaran, dan secanggih apapun inovasi pendidikan, tidak akan pernah ada artinya. Tanpa guru profesional, sumber daya manusia semacam apa yang akan dilahirkan?

Di sinilah terletak pentingnya keteladanan dari seorang guru profesional. Guru teladan akan selalu mempertanyakan, perubahan apa yang sudah terjadi pada peserta didiknya? Dia merasa sangat khawatir jika anak-anak yang dididiknya tidak punya jati diri, kehilangan arah, cerdas tapi tak bermoral, pinter tapi kabalinger. Guru teladan akan merasa risau jika budaya mencontek di sekolah tetap dibiarkan, risau jika peserta didiknya lebih suka tawuran daripada diskusi ilmiah di kampusnya, risau jika rekannya jual-beli karya ilmiah, sedih melihat sejawatnya terlibat korupsi dana bantuan operasional sekolah. Guru yang jiwanya sarat keteladanan, akan murka jika sudah tampak pertanda perubahan paradigma, dari tut wuri handayani menjadi tut wuri nggerogoti (di belakang menggerogoti), dari ing madya mangun karsa menjadi ing madya ngangkut banda (di tengah mengangkut harta), dari ing ngarsa sung tulada menjadi ing ngarsa trus ngapusi (di depan selalu menipu). ${ }^{18}$ Dia akan terus mempertanyakan, apakah dirinya sudah bisa memberi contoh pendidikan yang berkarakter, penuh dengan nilai-nilai humanisme, dan memberikan garansi bahwa belajar bersamanya merupakan saat terbaik untuk membangun masa depan.

${ }^{18}$ Sapa'at, A. Stop Menjadi Guru. (Jakarta: PT. Tangga Pustaka, 2012), h. 12. 


\section{Kapasitas, Kapabilitas, dan Karakter Guru}

Eri Sudewo menyebut $3 \mathrm{~K}$ sebagai kunci penentu sukses hidup seseorang. Kapasitas, kapabilitas, dan karakter. ${ }^{19}$ Kapasitas itu daya tampung. Karena anugerah, setiap orang berbeda kapasitasnya. Kemampuan memanfaatkan kapasitas, itulah kapabilitas. Karakter adalah sejumlah sifat baik yang menjadi perilaku sehari-hari. Jika sejak kecil punya kecerdasan luar biasa, pandai mengajar, itulah salah satu tanda seseorang punya kapasitas untuk menjadi guru. Kemudian alangkah hebatnya jika kapasitas tersebut dikembangkan dengan melakukan berbagai cara, misal sekolah di sekolah pendidikan guru (SPG-zaman dulu), atau kuliah di universitas keguruan. Lantas hidupnya disempurnakan dengan sifat baik yang setia ditunjukkan dalam perilaku kesehariannya. Semakin hebat karier profesionalnya, semakin ikhlas mengajarnya. Jika gaji tak mampu mencukupi hidupnya, tekad pengabdiannya justru semakin teruji. Itulah guru berlisensi 3K, sosok yang mampu membantu bangsa ini keluar dari keterpurukan dan mampu membentuk karakter anak-anak bangsa.

Guru tanpa karakter, walau kapasitas dan kapabilitasnya hebat, bisa jadi hidupnya celaka dan mencelakakan orang lain. Dulu tidak mau menjadi guru, tapi karena ada kemungkinan jadi lebih kaya, kini niatnya berubah ingin jadi guru. Jika ditugaskan di kota siap melakoninya, namun ketika ditugaskan di desa, jadi guru setengah hati terpaksa dijalani. Bagi guru berkarakter, uang dan segala kenikmatan dunia lainnya adalah fasilitas hidup, bukan tujuan hidup. Dia mencermati kapasitas dirinya, lalu belajar terus untuk meningkatkan kapabilitas diri. Dia tidak silau oleh kemegahan dunia, sederet gelar terhormat, struk gaji yang mencengangkan dan kendaraan hebat yang ditungganginya. Karena semua itu takkan dibawa mati. Baginya mewariskan ilmu bermanfaat dan menjadikan siswanya jadi anak-anak yang saleh, tujuan utama yang hendak dituju. Guru berkarakter, hidupnya selamat dan menyelamatkan orang-orang yang dididiknya. Sesungguhnya hidupnya adalah cerminan keluasan

${ }^{19}$ Kusdiyono. Guru 3K. [online]. Tersedia: http://kusdiyono.wordpress.com L2012/11/20/guru-3k/. 
ilmu, kekokohan jiwa pengabdian dan teladan sempurna untuk diikuti peserta didiknya.

\section{Guru Sebagai Fasilitator}

Banyak guru yang beranggapan, bahwa para peserta didik yang buruk kepada kulitas yang lebih baik, akan dijamin Tuhan keluasan rezekinya, datang ke ruang kelasnya belum tahu apa-apa, dan harus diberi tahu olehnya. Berkebalikan dengan ungkapan dari filosof bernama Plutarch, "Jangan pernah anggap bahwa pikiran peserta didik yang datang itu seperti wadah kosong yang bisa kita isi, tapi sebatang lilin yang siap dinyalakan!". Sejak ribuan tahun lalu Plutarch mewanti- wanti bahwa sebenarnya setiap peserta didik punya potensi yang siap dikembangkan. Itu artinya, mari ubah paradigma tadi! Guru bukan lagi sebagai penuang air di wadah yang kosong, tetapi lebih kepada perannya sebagai penyiram tanaman. Siswa sebagai tanaman punya potensi untuk tumbuh sendiri, menjulang sebagaimana yang dia kehendaki. Guru memfasilitasi anak yang dididiknya untuk tumbuh ke arah yang benar dengan memberinya sebatang turus (pedoman).

Anak sebagai knowledge builder, memperoleh ilmunya sebagai hasil jerih payahnya dalam membangun pengetahuannya sendiri. ${ }^{20}$ Saat anak menemui kesulitan, anak tidak dimanja dengan memberitahunya, tetapi terus didorong dan difasilitasi untuk berupaya keras mengkonstruksi pemahaman baru dengan modal pemahaman awal yang mereka bawa dari lingkungannya (prior knowledge) dengan melibatkan semua alat inderanya. Guru yang menjadi fasilitator, akan menanamkan sikap kerja keras kepada peserta didiknya, sehingga peserta didik mampu memaknai bahwa bagaimanapun pentingnya cara memulai sesuatu, jauh lebih penting cara mengakhiri dan memperoleh hasil terbaiknya. ${ }^{21}$

${ }^{20}$ Vygotsky, L.S., Mind in Society: The Development of Higher Psychological Processes. M. Cole, V. John Steiner, S. Scribner, \& E. Souberman, Eds.. (Cambridge, MA: Harvard University Press, 1978), h. 150.

${ }^{21}$ Ruffalo, R. \& Moretti, M. PEP, The Seven P's to Positively Enhance Performance. (Lyndon Saputra, Ed.). Batam Center: Interaksara, 2004. 


\section{Guru Muhajirin}

Istilah muhajirin dapat diartikan sebagai “orang yang berhijrah”. Hijrah bukan hanya berarti pindah tempat, tetapi juga berpindah dari sifat/kualitas buruk kepada sifat/kualitas baik, memiliki perencanaan yang matang dan melakukan ikhtiar secara maksimal. Sebagaimana firman Allah SWT dalam Alquran:

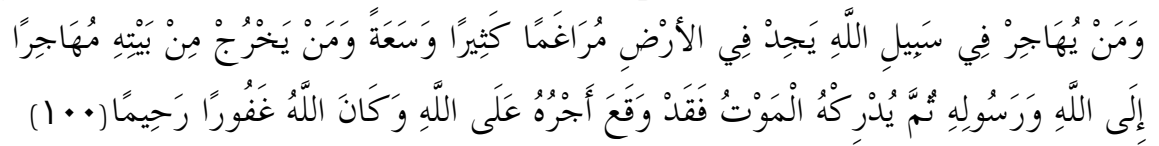

"Barangsiapa berhijrah di jalan Allah, niscaya mereka mendapati di muka bumi ini tempat hijrah yang luas dan rezeki yang banyak. Barangsiapa keluar dari rumahnya dengan maksud berhijrah kepada Allah dan Rasul-Nya, kemudian kematian menimpanya (sebelum sampai ke tempat yang dituju), maka sungguh telah tetap pahalanya di sisi Allah. Dan adalah Allah Maha Pengampun lagi Maha Penyayang” (QS. An-Nisa/4: 100).

Seperti yang diyakini penulis, bahwa Tuhan Yang Maha Benar telah menjanjikan kelapangan serta rezeki yang banyak bagi siapapun yang mau berhijrah. Lalu apa hubungan antara guru dan hijrah? Apa bedanya antara guru yang berhijrah dan guru yang tak mau berhijrah? Merujuk pada nukilan ayat di atas, jelas bahwa siapapun termasuk guru yang menghijrahkan dirinya dari kualitas dirinya yang kelapangan hidupnya, serta ketenangan jiwanya. Dalam hal ini, ada beberapa tolok ukur untuk melihat sejauhmana seorang guru telah berhijrah antara lain: lama mengajar, karya/buah pikiran, dan capaian peserta didiknya.

Pertama, lama mengajar berarti rentang waktu yang sudah dihabiskan untuk beraktivitas sebagai guru. Jika sudah 10 tahun mengajar, apakah cara mengajar tahun kesepuluh masih sama dengan tahun pertama mengajar? Jika sudah 30 tahun, masih samakah kualitas mengajar di tahun ketigapuluh itu dengan tahun perdana saat pengangkatan diri jadi guru? 
Kedua, karya atau buah pikiran yang telah dihasilkan. Mari pertanyakan, adakah hal baru yang diciptakan untuk memfasilitasi anak dalam belajar, entah itu temuan media, metode, atau strategi pembelajaran? Sudah berapa banyak tulisan yang dipublikasikan? Sudah berapa banyak karya penelitian yang diterbitkan? Apakah selama 10 atau 30 tahun menjadi guru tak pernah tercipta karya sendiri yang bisa dibanggakan?

Ketiga, setelah bertahun-tahun menjadi guru, sudah berapa banyak peserta didik yang terinspirasi dan sekarang menjadi para pejabat yang jujur, penguasa yang adil, pemimpin yang amanah, dan kaum profesional yang ber-akhlaqul karimah? Jika memang banyak peserta didik yang mencapai kehidupan mulianya, bersyukur hatilah. Karena Tuhan menjadikan kita (guru) sebagai bagian dari keberhasilan mereka.

Seandainya nyaris tak ada perbedaan antara tahun pertama dengan tahun kesekian sejak menjadi guru, maka sangat patut dipertanyakan sudah seprofesional apa guru itu? Jika setelah mendapat sertifikat profesi kemudian mengajar masih seperti seorang pemula yang asal-asalan, masih layakkah sertifikat itu dibanggakan? Jika guru memiliki iman dan dengan ikhlas menggunakan logikanya, maka kekeliruan yang selama ini terjadi akan dia sadari, untuk kemudian kegiatan hijrah pun segera dijalani.

Guru yang memahami makna hijrah, tentu akan merasa “diawasi" dan setiap tingkah lakunya dievaluasi. Ketika guru menancapkan tekad dalam dirinya untuk menjadi teladan, maka dia akan selalu bersikap mawas diri. Segala kekurangan diri akan dibenahi, dan refleksi selalu dilakoni. Hasilnya jelas, bahwa guru yang berhijrah akan sangat mudah dikenali. Seiring waktu dia semakin patut digugu dan ditiru. Semakin lama menjadi guru, semakin tampak sikap bijaksana dan tawadhu. Cara bicara guru yang berhijrah akan semakin mencerahkan, karena wawasannya semakin luas seiring semakin luasnya ruang baca dan diskusi. Adapun namanya, semakin dikenal karena karyanya bermunculan di mana-mana.

Hal yang tidak kalah pentingnya dalam konsep hijrah ini adalah: "hijrah harus total". Kalau memang sudah bertekad untuk menjadi 
orang baik, jangan dicicil. Jika memang berharap bebas dari kehidupan yang buruk dengan segera, berharap kesejahteraan yang segera, maka berubahlah segera! Andai kita mau benar-benar disegerakan menuju kepada kehidupan yang lebih baik, pindahlah secara total! Baikkan segera hati, baikkan segera pikiran, baikkan segera perbuatan. Lalu ikhlaslah, karena setiap orang yang menyatakan dirinya akan menjadi orang baik, maka pasti akan diuji kepantasannya pada kehidupan barunya. Bagaimanapun, tidak ada orang lama yang pantas bagi kehidupan baru.

\section{Penutup}

Seseorang yang getaran hatinya dipenuhi semangat mendidik serta detak jantungnya yang sarat keinginan untuk menjadi guru, sudah menjadi keniscayaan bahwa dirinya dituntut profesional. Terlebih lagi jika dia pun sudah menerima sertifikat pendidik, maka menjadi profesional adalah sebuah kewajiban. Dengan kata lain, akan sangat berdosa jika guru yang sudah memiliki sertifikat pendidik, namun perilakunya tidak mencerminkan diri yang profesional. Sebagai penutup tulisan ini, berikut akan diulas kembali poin inti dari ciri guru profesional yang diharapkan dapat menjadi rambu-rambu bagi siapapun yang tak berhenti belajar untuk mengembangkan profesionalisme dirinya.

Pertama, seperti diungkap dalam al-hadits, bahwa sebaik-baik manusia adalah yang paling banyak menebar mafaat bagi sesama. Begitu pula sebaik-baik guru, adalah mereka yang menyedekahkan ilmu yang dimilikinya kepada sebanyak-banyaknya peserta didik. Kedua, guru profesional memiliki kompetensi yang tak lagi diragukan. Dia selalu mempunyai tenaga untuk peserta didiknya, senantiasa memberi perhatian pada peserta didik di setiap ruang pembicaraan yang dilakukan dan punya kemampuan mendengar dengan saksama. Apa yang dilakukan guru profesional selalu dilatarbelakangi oleh tujuan yang jelas, tidak hanya tujuan saat pembelajaran, bahkan dampak ke depan yang bisa dicapai oleh siswanya di dunia nyata. Guru profesional mempunyai keterampilan untuk mendidik agar peserta didik disiplin dan konsisten, yang tentunya disiplin dan konsistensi itu 
pertama kali harus diperlihatkan oleh sang guru sebagai bentuk keteladanan. Guru profesional pasti mempunyai keterampilan manajemen di dalam kelas yang baik sehingga bisa memastikan bahwa perilaku peserta didik menjadi baik saat peserta didik belajar dan bekerja sama dalam komunitasnya. Tak bisa dilupakan, bahwa guru pun harus bisa berkomunikasi secara baik dengan orangtua peserta didik agar mereka selalu mengerti tentang informasi yang sedang terjadi.

Ketiga, guru profesional adalah mereka yang memiliki pengetahuan perihal kurikulum dan kesanggupan untuk mengimplementasikannya, dan bukan cuma mengutuk atas perubahan kurikulum yang akan terus terjadi. Dengan pengetahuan itu, guru dengan sekuat tenaga akan memastikan bahwa pengajaran yang mereka lakukan sudah memenuhi standar-standar yang dikehendaki. Guru harus juga berpengetahuan luas dan antusiasme yang besar mengenai subjek yang diajarkannya, dan selalu mencari apa yang baru sehingga pengetahuan saat ini tidak akan pernah sama dengan pengetahuan sebelumnya. Guru tersebut selalu siap untuk menjawab semua pertanyaan dan menyimpan berbagai bahan yang menarik bagi peserta didik. Pendeknya, guru profesional tidak akan pernah berhenti belajar, karena dengan itulah dia menunjukkan rasa syukurnya.

Keempat, keteladanan dan keikhlasan adalah cara berjuangnya. Apapun yang diajarkan selalu diawali dengan keteladanan, dan dia selalu memberikan yang terbaik bagi peserta didiknya. Dorongan keikhlasan dalam jiwanya akan selalu membuat dirinya bergairah saat mendidik meski menghadapi masalah pelik. Kelima, tidak hanya memiliki kapasitas dan kapabilitas, tapi sosok guru profesional juga akan mudah diidentifikasi wujud karakternya sebagai pembelajar sejati. Sejalan dengan waktu, kualitas dirinya selalu ditingkatkan. Dia selalu mengevaluasi kinerja diri, karena dia menyadari betul bahwa apa yang kini diperbuatnya pasti akan dipertanggungjawabkan, tidak hanya didepan petingginya, tetapi juga di hadapan Yang Maha Tinggi. Apapun yang dilakukannya senantiasa diukur sebesar apa dampak baiknya, dan ditakar seberapa dalam itu mampu menginspirasi peserta didiknya. 


\section{Daftar Pustaka}

Al-Quran al-Karim dan Terjemahannya. Jakarta: Departemen Agama Republik Indonesia.

Abu Ahmadi. Ilmu Pendidikan. Jakarta: Rineka Cipta, 1991.

Boediono, ed. Standar Kompetensi Pendidikan Anak Usia Dini Taman Kanak- Kanak dan Raudhatul Athfal, Jakarta: Departemen Pendidikan Nasional, 2003.

Fasli Jalal. "Peran Pendidikan Non Formal dalam Pembangunan Manusia Indonesia yang Cerdas Dan Bermutu", dalam Seminar Sosialisasi Nasional Pendidikan Non Formal. Universitas Negeri Yogyakarta.

Hartoyo. Konsep Dasar Pendidikan Anak Usia Dini, Materi Tutor dan Pengelola Pendidikan Anak Usia Dini, di BPPLSP Regional III Jawa Tengah, 2004. http://www.brainyquote.com/quotes/quotes/w/williamart103463 .html

Imam al-Hafidz Abi 'Abbas Muhammad ibn 'Isa ibn Saurah at-Tirmizi. Sunan at-Tirmizi al-Jami’us Sahih, juz 3. Semarang: Toha Putra, tt.

James H. Mc Milllan dan Sally Schumacher. Research in Education: A Cconseptual introduction. New York: Longman, 2001.

Kusdiyono.

Guru

$3 K$.

[online].

Tersedia:

http://kusdiyono.wordpress.com/ 2012/11/20/guru-3k/, 2001.

M. Athiyah Al Abrasy. At-Tarbiyah al-Islamiyah wa Falsasfatuha. t.t.p: Isa al-Babi al-Jalabi wa syirkahu, 1969.

Mansur. Pendidikan Anak Usia Dini dalam Islam. Yogyakarta: Pustaka Pelajar, 2005.

......... Diskursus Pendidikan Islam. Yogyakarta: Global Pustaka Utama, 2001. 
Maulana. Kemandirian Belajar Guru Sekolah Dasar (Studi Deskriptif terhadap Guru SD dari Enam Kabupaten di Jawa Barat). Jurnal Mimbar Pendidikan Dasar. Volume 4, No.1, Februari 2013.

Muhammad Zuhaili. Al Islam Wa Asy Syabab, terjemahan Arum Titisari, Pentingnya Pendidikan Islam Sejak Dini. Jakarta: AH. Ba'adillah Press, 2001.

Napitupulu. Komitmen dan Setrategi Pelayanan Pendidikan Untuk Semua, dalam Bulletin PAUD, Direktorat Pendidikan Anak Usia Dini, Depdiknas, Jakarta, 2002.

Noeng Muhadjir. Metodologi Penelitian Kualitatif. Yogyakarta: Rakesa Rasin, 1995.

Ramayulis. Ilmu Pendidikan Islam, Jakarta: Kalam Mulia, 2006.

Ruffalo, R. \& Moretti, M. PEP: The Seven P's to Positively Enhance Performance. Lyndon Saputra, Ed. Batam Center: Interaksara, 2004.

Sapa'at, A. Stop Menjadi Guru. Jakarta: PT. Tangga Pustaka, 2012.

Saud, U.S. \& Sutarsih, C. Pengembangan Profesi Guru SD. Bandung: UPI Press, 2007.

Sutisna.Pengertian Kemandirian Belajar.[online]. Tersedia: 2010. http:// sutisna. com/ artikel/ kependidikan/ pengertiankemandirian/.

Undang-Undang Republik Indonesia Nomor 14 Tahun 2005 tentang Guru dan Dosen.

Undang-Undang Republik Indonesia Nomor 20 Tahun 2003 tentang Sistem Pendidikan Nasional.

Vygotsky, L.S. Mind in Society: The Development of Higher Psychological Processes. M. Cole, V. John Steiner, S. Scribner, \& E. Souberman, Eds. Cambridge, MA: Harvard University Press, 1978. 